\title{
The Effects of Writing Strategy Instruction on EFL Learners' Writing Development
}

\author{
Ai-hua Chen ${ }^{1}$ \\ ${ }^{1}$ Department of English Language, Literature and Linguistics, Providence University, Taiwan \\ Correspondence: Ai-hua Chen, English Department, Providence University, Taichung, Taiwan.
}

Received: January 26, 2022

Accepted: February 17, $2022 \quad$ Online Published: February 21, 2022

doi: 10.5539/elt.v15n3p29

URL: https://doi.org/10.5539/elt.v15n3p29

\begin{abstract}
This study examined the effects of integrating writing strategy training into EFL writing instruction on learners' strategy use and writing performance. Two classes of EFL adult learners participated in this study. The experimental group were instructed with the writing strategy training in their EFL writing class for 14 weeks, whereas the control group received the same EFL writing program without any explicit strategy training.

Mixed methods were applied in collecting data. The quantitative instruments included the writing strategy questionnaires and writing performance tests, which were both pre-tested and post-tested in the both groups. The qualitative instruments of reflective journals were also conducted in the experimental group to probe deeper insights into learners' strategy changes. The findings showed that there were significantly positive differences in learners' using writing strategies and in writing proficiency favoring the experimental group.

The findings of this study indicate that writing strategy training can be integrated in the EFL writing instruction, and can bring to positive impacts for learners' strategic awareness and writing strategy use as well as their writing performance. The paper suggested the strong need to the process-based writing instruction, and writing strategy training holds promise in this regard.
\end{abstract}

Keywords: EFL writing strategies, strategy training, writing strategy instruction

\section{Introduction}

Since English is the global lingua franca, the major language of international communication, and English writing is one of the most important communication means that connects us to the world (Reid, 1993). Hence, English writing instruction in particular, cannot be overemphasized. The importance of EFL writing has been given more attention both internationally and domestically in recent years (Graham et al., 2013). For example, TOEIC (The Test of English for International Communications) has upgraded to include the writing test section since 2006. In addition, Taiwan's university entrance exam, the General Scholastic Ability Test, has also included writing test in English language subject.

Writing skill has been mostly seen as the most difficult and multifaceted skill to comprehend and learn both in their native and foreign languages. Likewise, for most EFL teachers in universities, teaching English writing is probably one of the most challenging and frustrating experiences in helping students develop their writing skill. Although teachers have devoted efforts in teaching writing, many students' writing performance remains unsuccessful in content organization, idea development and grammar structures, not to mention the lack of varieties in sentence structures and the weakness in vocabulary usages.

The reason for this frustrating experience is that writing is one of the highly complicated and difficult processes, which involves active processing in both comprehension and production among EFL learners (Graham et al., 2013). However, for students who used to be passive recipients of information in traditional EFL classrooms, they may have great difficulties in activating their thinking processes, generating ideas and organizing structures to construct a comprehensive composition. Furthermore, they are usually unaware of their writing problems occurred in their processing of writing, leading to their poor writing performances as well as their frustration in EFL writing. As a result, students' writing performance has remained disappointing. It appears that test-oriented instruction has been predominant in university EFL classrooms in Taiwan at the cost of students' development of autonomous and process-based learning, which is a very important component in tertiary education. 
Perhaps a new perspective needs to be taken in EFL pedagogy generally and in EFL writing more specifically. As the research has suggested, language teaching concerns should place greater emphasis on learning contexts and thinking processes, in which language learning strategies play a crucial role. Therefore, in the teaching of EFL writing, there is an urgent need for teachers to explore students' learning processes, and teaching writing strategies may hold promise in this account. In this premise, it is suggested that more specific studies on writing strategy instruction need to be conducted to examine the effectiveness of writing strategy instruction on EFL learners' writing process and writing performance.

\section{Literature Review}

\subsection{Writing Strategies}

Regarding the four language skills, writing is concerned as the most difficult skill either in one's first language or in a second/foreign language (Richard \& Renandya, 2002). Writing involves a complicated process in which learners have to actively generate ideas, organize and construct information in different genres, as well as revise and edit the text (Ferris \& Hedgcock, 2011).

There is a consensus among EFL learners that learning to write effectively is probably one of the most frustrating experiences. A wide range of writing difficulties encountered by EFL writers have also been identified (e.g., Abas \& Bakir, 2013; Kao \& Reynoldsb, 2017; Myles, 2002) to provide teachers with a better understanding of students' problems in constructing a text, i.e., the difficulty to develop ideas in the second/foreign language (L2/FL), inconsistency in ideas organization, incorrect grammar structures, inappropriate vocabulary use, and a lack of strategic awareness in writing process.

To help learners overcome their writing problems during the process of writing, writing strategies have been proposed as useful tools, techniques or operations that learners can employ to write more effectively (Creswell, 2000; Graham, 2006). Flower (1998) described writing strategies as decisions made by the writer to deal with the problems encountered in the writing task. Graham et al. (2013) also indicated writing strategies as techniques the writers consciously employ to develop ideas, plan, organize, revise, and reflect in the process of writing. Since writing strategies involve an active and complex process and play a role in L2/FL writing, there have been a wide set of studies investigating writing strategies used by L2/FL learners over the past two decades.

These studies include the kinds of the writing strategies used (e.g., Chien, 2012; Kao, 2010), the strategy use from sociocultural perspectives (e.g., Lei, 2016; Simeon, 2016), and the strategies used in different texts, tasks, and settings (e.g., Bai, 2018; Kost, 2011). Although research has focused on a number of different topics, most studies have contrasted strategy use between more and less successful writers, with the aim of identifying effective writing strategies that may help improve their writing performance.

The above two lines of descriptive studies have provided writing teachers a clear picture of their students' writing problems and strategy use. However, this raises a question of how to help learners to employ effective strategies and solve their writing problems. The issue remains to be adequately explored and leads us to the next question of how writing strategy instruction can be best provided, in which the key is to help learners to raise strategic awareness and metacognition (Harris et al., 2010).

\subsection{Studies on Writing Strategy Instruction}

Metacognitive awareness or metacognition has been defined as thinking about cognition (Anderson, 2012). It includes both metacognitive knowledge and strategy use. The regulation of metacognitive strategies not only guides learners to plan, monitor and evaluate their own learning process, but also enhances the development of cognitive skills (Wenden, 1999).

Regarding EFL writing instruction, one way to help learners to reinforce their metacognitive awareness is to keep learner diaries or reflective journals over time so as to consistently stimulate learners' reflections on their processes of learning to write (Chanski, 2015). Enhancing metacognitive knowledge may positively help learners take control of their language learning process in writing skills that students can plan, monitor, and evaluate their writing process effectively (De Silva \& Graham, 2015).

Studies on writing strategy instruction have received greater attention and these empirical studies have indicated the positive impacts of writing strategy instruction on learners' strategy awareness raising, strategy development and writing performance (e.g., Cer, 2019; De Silva \& Graham, 2015; Grenfell \& Harris, 2017; Mastan et al., 2017; Simeon, 2016). However, very limited studies have been conducted in the context of EFL writing instruction in Taiwan. The question arises whether the writing strategy instruction would result in positive effects on EFL learners' writing development, where most students have been influenced by the strong washback effects of testing (Chen, 2013). 
Thus, there is a strong need to conduct writing strategy instruction in a more conventional writing classroom context. This study thus intends to investigate the effects of writing strategy instruction on students' writing strategy use and writing performance for Taiwanese EFL university students.

\section{Methodology}

\subsection{Research Questions}

This classroom-based study aimed to investigate the effects of writing strategy instruction, namely, in expanding students' writing strategy use, in enhancing their self-directed learning in writing and in improving their EFL writing proficiency. More specifically, the research questions guiding this investigation are:

1) Does writing strategy instruction improve students' use of writing strategies?

2) Does writing strategy instruction improve students' writing proficiency?

\subsection{Participants}

In order to manipulate the variables which might affect the intervention design, such as class size, school year, students' majors and EFL proficiency, two classes with similar EFL learning backgrounds were selected to participate in this study. The students in these two classes were freshmen majoring in English department in one university in Taiwan.

They had learnt English in school settings for at least 6 years, and their English proficiency ranged from low-intermediate to intermediate level. The two classes were enrolled in the course-Beginning English Composition, with two hours of classes each week. One class was randomly assigned as the experimental group (Class A) and the other as the control group (Class B). Both experimental and control groups attended the same writing program with the same instructor, materials, and assignments for 14 weeks. In the experimental group, students received explicit writing strategy instruction integrated into the regular writing class. They were also required to complete the strategy-regulation checklist right after they completed a writing task. As for the control group, students were only taught about the text content and features of model essays, but without any mention to specific strategies for regulating the processes by which these texts might be produced implicitly.

\subsection{Writing Strategy Instruction}

A number of research studies (e.g., Chamot, 2005; Oxford, 2017) have proposed the models of strategy instruction, and some of these studies have shown its effectiveness in the language learning. This study adopted the suggested models from the research and designed the more appropriate procedures in a context of Taiwanese university students.

The in-class writing strategy instruction procedures were as follows:

1) Strategic-awareness raising phase: the teacher tried to raise students' strategic awareness by using think-aloud procedures. Ask students about how they write, what they think about while writing, and what problems they might encounter during the writing process. By doing so, students could become more aware of their strategy use while they were writing.

2) Demonstration phase: the teacher modeled the appropriate strategies for the writing task demands of different genres in this session. The teacher composed out loud in front of students and spoke the thought while writing, showing students how the particular strategies can be used in the different stages of writing process. The writing strategies for before, during and after the writing task were explicitly explained and modeled.

3) Practice phase: Students practiced the modeled strategies through similar writing tasks with the strategy-regulation checklist reminders of strategies for before, during and after writing. In the latter sessions of the writing strategy instruction from week 11 to week 14, reminders of scaffolding about strategy use were gradually removed.

4) Evaluation phase: students were required to complete the reflective journal right after they completed a writing task in class and to self-evaluate the effectiveness of the writing strategies that they employed during the writing task.

The writing strategies taught to the experimental group are the general model strategies that have been suggested from Oxford (2017). See Table 1. 
Table 1. Strategies Taught to the Experimental Group

\begin{tabular}{|c|c|c|}
\hline Writing Strategies & Sub-strategies & Speculation \\
\hline \multirow[t]{9}{*}{ Metacognitive Strategies } & Planning & Analyzing the task purpose \\
\hline & & Using a graphic organizer \\
\hline & & Setting the writing goal \\
\hline & Monitoring & Checking the relevance of content \\
\hline & & Checking the grammar and vocabulary \\
\hline & & Identifying writing problems \\
\hline & Evaluating & Rereading, Revising and Editing \\
\hline & & Reconsidering written text and goals \\
\hline & & Evaluating what I did more or less well \\
\hline \multirow[t]{6}{*}{ Cognitive Strategies } & Generating ideas & Brainstorming, inferencing \\
\hline & Revising & Making changes and revisions in written text \\
\hline & Elaborating & Relating new information and details \\
\hline & Clarification & Clarifying words and ideas \\
\hline & Retrieval & Getting information from memory \\
\hline & Summarizing & Synthesizing the written text \\
\hline \multirow[t]{3}{*}{ Social/affective Strategies } & Resourcing & Referring to dictionaries or resources \\
\hline & Getting feedback & Getting advices from teachers and peers \\
\hline & Confidence building & Encouraging oneself and reducing anxiety \\
\hline
\end{tabular}

\subsection{Instruments and Research Procedure}

\subsubsection{Writing Strategy Questionnaires}

This study incorporated and adapted three validated English writing strategy inventories from research studies (Hwang \& Lee, 2017; Petric \& Czárl, 2003; Raoofi et al., 2017). The questionnaire adopted a 5-point frequency scale ('almost never', 'seldom', 'sometimes', 'often', and 'almost always'). There was also a pre-section to collect the subjects' background information included on the writing strategy questionnaire, to elicit information regarding the subjects' gender, age, the years of learning English, and their perceptions of learning EFL writing. Before it was administered to the participants, the validity of the questionnaire was checked and ensured by an expert. In addition, the questionnaire was also pilot-tested to confirm its reliability. The Cronbach's alpha results were $.86, .80$, and .87 for metacognitive, cognitive, and social/affective strategies respectively. The Writing Strategy Questionnaire was employed to be both pre-tested and post-tested in both experimental group and control group in order to measure the changes of writing strategy use after writing strategy instruction.

\subsubsection{Writing Performance Test}

Two writing topics for opinion essays were selected for the pretest and the posttest. Students were required to write the opinion essay about 300 words for forty minutes in each test. Regarding the writing performance tests, the writing rubric was adapted from Connor-Linton and Polio (2014) and Jacobs et al. (1981), which comprises five writing aspects such as content, language use, organization, vocabulary, and mechanics. The total of the score has a range of $0-100$. The first aspect of content consists of 30 points, language use contains 25 points, organization and vocabulary equally has 20 points each and finally mechanics only includes 5 points.

Prior to the writing strategy training, the writing pre-test was conducted to both experimental and control group students. After 14-week of writing strategy instruction to the experimental group, the essay writing post-test was also employed to both experimental and control groups. The Writing Performance Tests were conducted both at the pre-test and the post-test in both two groups to measure the changes of students' writing performances after writing strategy instruction.

\subsubsection{Reflective Journals}

To probe insights into students' writing strategy change, experimental group students were required to complete reflective journals right after they completed their writing tasks every other week. The instrument of reflective 
journals served not only as treatments to stimulate students' strategic awareness regarding their writing tasks, but also as indicators of their changing processes of strategy use over time. For the intervention, students were required to complete reflective journals every other week through the 14-week period of training. However, with an aim to examine the changes over longer and potentially more meaningful intervals, only the first set (week 2), the middle set (week 8) and the last set (week 14) of each subject's reflective journals were sampled and analyzed. The purpose of collecting students' reflective journals over time was to examine how students might develop their metacognitive awareness and adjust their strategy use during the process of strategy instruction.

\subsection{Data Analysis}

Both the data from the questionnaires and writing tests conducted to the experimental and control groups at pre-test and post-test were collected and then analyzed by using SPSS 26. The data from the questionnaires were analyzed to calculate the mean and standard deviations of students' choices in writing strategy use at two times, pre-test and post-test. Furthermore, the data of the two group students' opinion essay scores in the pre-test and post-test were also analyzed by using descriptive statistics.

The essays were marked by the researcher and another English teacher who was not involved in the study. The inter-rater reliabilities for the scorings of pre-test and post-test were .81 and .88 respectively, and any discrepancies were resolved through discussions. The score for each writing essay was the average of the scores rated by the two independent raters.

As for the qualitative data, in order to examine an individual case's qualitative change of strategy use over time in terms of appropriateness and orchestration, the written records of subjects' retrospections on the strategy use for the writing tasks were narratively interpreted so as to probe whether individuals adjusted their strategy use in more effective manners. In addition, a strategy matrix for each set of reflective journals was created in order to systematically compare and analyze the changes of strategy use in qualities within each case and further across different cases.

\section{Results and Discussion}

\subsection{Effect of Writing Strategy Instruction on Writing Strategy Use}

\subsubsection{Results of Writing Strategy Questionnaires}

The results of Writing Strategy Questionnaires showed that there were significant differences in all categories (see Table 2), i.e. for Metacognitive Strategies $(\mathrm{F}=9.16, \mathrm{p}<.01)$, Cognitive Strategies $(\mathrm{F}=5.87, \mathrm{p}<.05)$, and Socio/Affective Strategies $(\mathrm{F}=10.74, \mathrm{p}<.01)$.

Table 2. Interaction Effects of Time x Group and Mean frequencies in Writing Strategies of Pre-test and Posttest Results for Control and Experimental groups

\begin{tabular}{lllll}
\hline Interaction Effects of Time x Group & $\begin{array}{l}\text { Control Group } \\
(\mathrm{N}=25)\end{array}$ & $\begin{array}{l}\text { Experimental } \\
\text { Group (N=27) }\end{array}$ & $\begin{array}{l}\text { Time x } \\
\text { Group }\end{array}$ \\
\hline Writing Strategy Categories & Time & $M(\mathrm{SD})$ & $M(\mathrm{SD})$ & $\mathrm{F}$ \\
Metacognitive Strategies & Pre-test & $2.86(0.55)$ & $2.95(0.62)$ & $9.16^{* *}$ \\
& Post-test & $3.19(0.49)$ & $3.58(0.56)$ & \\
Cognitive Strategies & Pre-test & $2.76(0.65)$ & $2.72(0.54)$ & $5.87^{*}$ \\
& Post-test & $3.01(0.58)$ & $3.21(0.61)$ & \\
Socio/Affective Strategies & Pre-test & $2.87(0.53)$ & $2.81(0.55)$ & $10.74^{* *}$ \\
& Post-test & $3.08(0.62)$ & $3.36(0.52)$ & \\
\hline
\end{tabular}

$$
\text { Note. }{ }^{*} \mathrm{p}<.05 ; * * \mathrm{p}<.01 ; * * * \mathrm{p}<.001
$$

For the category of Metacognitive Strategies, the experimental group had significantly greater increases in mean frequency of these metacognitive strategies than did the control group. This indicated that students in the experimental group might have raised their strategy awareness and learned to be able to deploy the whole range of metacognitive strategies more automatically and systematically. They were more aware of using self-regulation strategies more effectively, i.e., pre-writing planning, while-writing monitoring and after-writing evaluating. In addition, these changes may be associated with the treatment of keeping reflective journals, which encouraged students to reflect on and track their learning successes and problems, such as their learning goals, problems encountered and attempted solutions. 
As for the category of the cognitive categories, the experimental group showed a significant difference in increasing the use of cognitive strategies than the control group. These results may be due to the introduction of more appropriate higher-level strategies during the intervention and thus suggest that strategy training may guide students to use strategies in more appropriate ways to process a writing task.

Finally, a greater significant difference was also found in the Socio/Affective subgroup, which originally was the less used category by all students before the writing strategy instruction. However, after the intervention of strategy training, the experimental group students reported to use Social and Affective strategies much more frequently than the control group.

\subsubsection{Results of Reflective Journals}

The three sets of reflective journals were completed by the experimental group students at weeks 2,8 and 14 respectively. Right after finishing writing tasks, students were required to complete the prompt questions in the reflective journals. Students reported positive changes in using writing strategies during the process of strategy training. For example, in the metacognitive strategies, many students stated that planning strategies were very helpful in helping them outlining the essays. One student stated that,

"Normally I would simply follow the essay models of writing introduction and thesis statement, but I just write and come up with ideas randomly. Now I know how to plan my outline with clear ideas before I start to write. By doing so, I have a clear direction of how to write and my writing performance is better now." (S9, RJ2)

Some students also reported that using monitoring strategies was very important in developing ideas and in checking the correlation of main ideas and supporting details. They stated that using monitoring strategies helps them raise awareness in constructing a well-organized essay. In addition, they became more aware of making changes of their writing texts on all levels at any time.

"Using monitoring strategies is very effective in writing essays, because it always reminds me in developing consistent ideas through the whole essay. Furthermore, I become more aware of some irrelevant ideas I first wrote and change them to correspond the main idea." (S16, RJ3)

Finally, some students became better able to employ a whole range of writing strategies more systematically to improve their writing. For instance, they tried to effectively use cognitive, metacognitive and socio-affective strategies in a more appropriate way.

"I used to write down whatever in my mind to complete the writing task, and my essay scores were very low. But now I become more careful in writing, I know how to generate organized ideas and I would check my arguments or grammar sentences all the time and finally revise again. My writing has been improving a lot and I become more confident in writing a good essay." (S20, RJ2)

"In the past, I only checked the grammar and vocabulary spelling after I finished, but now I would check my supporting arguments to see if they correlate with the main idea or not." (S13, RJ3)

From the results of experimental group students' reflective journals, it was found that the strategy training seemed to enhance students' metacognitive knowledge to harmonize their strategy use, writing difficulties, learning progress and other individual factors. As a result, they were better able to orchestrate their strategy use in an effective chain to perform the writing tasks more successfully. Hence, the findings of this study supported the De Silva and Graham's study (2015) indicating the positive impacts of exploring learners' writing processes that help learners probe deeper insights into their writing problems and solving strategies.

Based on the results of writing strategy questionnaires and reflective journals, both quantitative and qualitative results suggest the effectiveness of strategy training which guides students to improve and expand their strategy repertoires. Although students in the control group also increased their strategy use in three strategy categories, these trends were very slight compared to those in the experimental group. This change was probably due to writing strategies being embedded in general language instruction to some extent, although they were taught implicitly and sparsely. As a result, control group students used strategies randomly and unconsciously, showing very few differences in strategy use over time. Hence, this study confirms the effectiveness of teaching strategies explicitly to make students consciously reflect on their strategy use on a regular basis, so as to enhance the positive changes in expanding their strategy repertoires more significantly.

\subsection{Effect of Writing Strategy Instruction on Writing Performance}

First, the results of writing scores (see Table 3) indicated that there was a significant difference found for the interaction effect of time by group $(\mathrm{F}=8.87, \mathrm{p}<.01)$. This suggested that the experimental group showed a 
significant improvement in the mean writing scores from pretest to post-test compared to those of the control group.

Table 3. Interaction Effects of Time x Group and Means for Writing Scores

\begin{tabular}{cclll}
\hline \multirow{2}{*}{ Writing Performance Tests Scores } & $\begin{array}{l}\text { Control } \\
(\mathrm{N}=25)\end{array}$ & \begin{tabular}{l} 
Group \\
\cline { 2 - 5 }
\end{tabular} & $\begin{array}{l}\text { Experimental } \\
\text { Group }(\mathrm{N}=27)\end{array}$ & $\begin{array}{l}\text { Time } \mathrm{x} \\
\text { Group }\end{array}$ \\
\hline Writing Scores & Pre-test & $68.28(7.73)$ & $67.34(8.94)$ & $8.87^{* *}$ \\
$($ range $0 \sim 100)$ & Post-test & $71.65(6.65)$ & $79.25(6.08)$ & \\
\hline Note. ${ }^{*} \mathrm{p}<.05 ; * * \mathrm{p}<.01 ; * * * \mathrm{p}<.001$ & & &
\end{tabular}

This may be the result of experimental group students' more appropriate way of employing strategies to deal with writing tasks and more active self-regulation during the writing process. Therefore, with the writing strategy instruction, students performed their writing tasks more effectively and thus they had achieved higher writing proficiency after the strategy instruction.

Therefore, the quantitative results of writing proficiency tests indicated that the writing strategy instruction may have some positive effects on students' writing performance. The results of the present study are also supported by studies addressing the positive effects of the writing strategy on writing skills development (Cer, 2019; Grenfell \& Harris, 2017; Simeon, 2016).

\section{Conclusion and Implications}

This paper has shown that students improved not only in EFL writing proficiency but also in enhancing writing strategies. With the strategy instruction, students were better able to develop metacognitive awareness in using writing strategies. It proved the effectiveness of empowering students with the effective processing in EFL writing which resulted in positive outcomes.

Finally, consistent and systematic strategy instruction integrated into EFL writing is recommended. The findings of this study suggest the strong need for the teacher to play an active role in implementing strategy instruction at the initial stage. Furthermore, it is essential to develop students' metacognitive awareness and strategy use, which can be regarded as the key to effective writing. That is, to consistently familiarize students with the procedures of pre-writing planning, while-writing monitoring and after-writing evaluation. These regulations have been shown to empower learners in executing better control over their writing processing, to fine tune their own strategy repertoire and in turn, to efficiently perform their writing tasks. Once the strategy instruction is consistently scaffolded, the responsibilities of learning would gradually shift to learners themselves through their self-regulated writing processing. Hence, the writing strategy instruction could hold promise for helping learners both to improve their writing skills and to strengthen their learner autonomy.

\section{References}

Abas, D., \& Bakir, A. (2013). Writing Difficulties and New Solutions: Blended Learning as an Approach to Improve Writing Abilities. International Journal of Humanities and Social Science, 3(9), 254-266.

Anderson, N. J. (2012). Metacognition: Awareness of Language Learning. In Mercer, S., Ryan, S. \& Williams, M. (Eds.), Psychology for Language Learning. Palgrave Macmillan, London. https://doi.org/10.1057/9781137032829_12

Bai, B. (2018). Understanding primary school students' use of self-regulated writing strategies through think-aloud protocols. System, 78, 15-26. https://doi.org/10.1016/j.system.2018.07.003

Cer, E. (2019). The instruction of writing strategies: The effect of the metacognitive strategy on the writing skills of pupils in secondary education. Sage Open, 9(2), 1-17. https://doi.org/10.1177/2158244019842681

Chamot, A. U. (2005). The Cognitive Academic Language Learning Approach (CALLA): An update. In P. A. Richard-Amato \& M. A. Snow (Eds.), Academic success for English language learners: Strategies for K-12 mainstream teachers (pp. 87-101). White Plains, NY: Longman.

Chamot, A. U., \& O'Malley, J. M. (1994). The CALLA Handbook: Implementing the Cognitive Academic Language Learning Approach. White Plains, NY: Addison Wesley Longman.

Chanski, S. (2015). Assessing writing through metacognitive and reflective practice. Language Arts Journal of Michigan, 31(1), Article 10. https://doi.org/10.9707/2168-149X.2097 
Chen, A. (2013). EFL listeners' strategy development and listening problems: A process-based study. The Journal of Asia TEFL, 10(3), 81-101.

Chien, S. C. (2012). Students' use of writing strategies and their English writing achievements in Taiwan. The Asia Pacific Journal of Education, 32(1), 93-112. https://doi.org/10.1080/02188791.2012.655240

Connor-Linton, J., \& Polio, C. (2014). Comparing perspectives on L2 writing: Multiple analyses of a common corpus. Journal of Second Language Writing, 26, 1-9. https://doi.org/10.1016/j.jslw.2014.09.002

Creswell, A. (2000). Self-monitoring in student writing: Developing responsibility. ELT Journal, 3, 235-244. https://doi.org/10.1093/elt/54.3.235

De Silva, R., \& Graham, S. (2015). The effects of strategy instruction on writing strategy use for students of different proficiency levels. System, 53, 47-59. https://doi.org/10.1016/j.system.2015.06.009

Ellis, A., Bond, J. B., \& Denton, D. W. (2012). An analytical literature review of the effects of metacognitive teaching strategies in primary and secondary student populations. Asia Pacific Journal of Educational Development, 1(1), 9-23. https://doi.org/10.6228/APJED.01.01.02

Ferris, D. R., \& Hedgcock, J. S. (2011). Teaching ESL Composition: Purpose, Process and Practice (2nd ed.). Routledge: New York.

Flower, L. (1998). Problem-solving strategies for writing in college and community (1st ed.). Fort Worth, TX: Harcourt Brace College Publishers.

Graham, S. (2006). Strategy instruction and the teaching of writing. A meta-analysis. In C. A. MacArthur, S. Graham \& J. Fitzgerald (Eds.), Handbook of Writing research. The Guilford Press.

Graham, S., Gillespie, A., \& McKeown, D. (2013). Writing: Importance, development, and instruction. Reading and Writing, 26, 1-15. https://doi.org/10.1007/s11145-012-9395-2

Graham, S., Harris, K. R., \& Mason, L. (2005). Improving the writing performance, knowledge, and self-efficacy of struggling young writers: The effects of self-regulated strategy development. Contemporary Educational Psychology, 30(2), 207-241. https://doi.org/10.1016/j.cedpsych.2004.08.001

Grenfell, M., \& Harris, V. (2017). Language learner strategies: contexts, issues and applications in second language learning and teaching. Bloomsbury, London.

Harris, K. R., Santangelo, T., \& Graham, S. (2010). Metacognition and strategies instruction in writing. In H. S. Waters \& W. Scheneider (Eds.), Metacognition, strategy use, and instruction (pp. 226-256). New York, NY: The Guilford Press.

Hwang, M., \& Lee, H. K. (2017). Development and validation of the English writing strategy inventory. System, 68, 60-71. https://doi.org/10.1016/j.system.2017.06.014

Jacobs, H. L., Zinkgraf, S. A., Wormouth, D. R., Hartfiel, V. F., \& Hughey, J. B. (1981). Testing ESL composition: A practical approach. Rowely, MA: Newbury House.

Kao, C. W., \& Reynolds, B. L. (2017). A study on the relationship among Taiwanese college students' EFL writing strategy use, writing ability and writing difficulty. English Teaching \& Learning, 41(4), 31-67. https://doi.org/10.6330/ETL.2017.41.4.02

Kao, C. W. (2010). An investigation into technological college student writers' English writing strategy uses. Journal of Applied Foreign Languages, 13, 49-70.

Kost, C. (2011). Investigating writing strategies and revision behavior in collaborative wiki projects. CALICO Journal, 28(3), 606-620. https://doi.org/10.11139/cj.28.3.606-620

Lei, X. (2016). Understanding writing strategy use from a sociocultural perspective: The case of skilled and less skilled writers. System, 60, 105-116. https://doi.org/10.1016/j.system.2016.06.006

Macaro, E. (2006). Strategies for language learning and for language use: Revising the theoretical framework. The Modern Language Journal, 90(3), 320-337. https://doi.org/10.1111/j.1540-4781.2006.00425.x

Mastan, M., Maarof, N., \& Embi, M. (2017). The effect of writing strategy instruction on ESL intermediate proficiency learners' writing performance. Journal of Educational Research and Review, 5(5), 71-78.

Myles, J. (2002). Second language writing and research. The writing process and error analysis in student texts. Teaching English as a second language or foreign language, 6(2), 1-19. 
Oxford, R. L. (1990). Language Learning Strategies: What Every Teacher Should Know. Newbury House, New York.

Oxford, R. L. (2017). Teaching and Researching Language Learning Strategies: Self-Regulation in Context (2nd ed.). Routledge, New York.

Petric, B., \& Czárl, P. (2003). Validating a writing strategy questionnaire. System, 31(2), 187-215. https://doi.org/10.1016/S0346-251X(03)00020-4

Raoofi, S., Miri, A., Gharibi, J., \& Malaki, B. (2017). Assessing and validating a writing strategy scale for undergraduate students. Journal of Language Teaching and Research, 8(3), 624-633. https://doi.org/10.17507/jltr.0803.23

Reid, J. M. (1993). Teaching ESL Writing. Englewood Cliffs, NJ: Prentice Hall Regents.

Richard, J., \& Renandya, W. (2002). Methodology in Language Teaching: An Anthology of Current Practice. Cambridge University. https://doi.org/10.1017/CBO9780511667190

Simeon, J. (2016). Learner writing strategies of Seychellois ESL secondary school students: A sociocultural theory perspective. Learning, Culture and Social Interaction, 8, 1-11. https://doi.org/10.1016/j.lcsi.2015.11.002

Wenden, A. L. (1999). An introduction to metacognitive knowledge and beliefs in language learning. System, 27, 435-441. https://doi.org/10.1016/S0346-251X(99)00043-3

\section{Copyrights}

Copyright for this article is retained by the author(s), with first publication rights granted to the journal.

This is an open-access article distributed under the terms and conditions of the Creative Commons Attribution license (http://creativecommons.org/licenses/by/4.0/). 